\title{
The Analysis Of Five William Blake's Poems
}

\author{
Sri Mulyati \\ Universitas Bina Sarana Informatika \\ sri.smq@bsi.ac.id
}

\author{
Cara Sitasi : \\ Mulyati, S. (2019). The Analysis of Five William Blake's Poems. Wanastra2, 11(2), 113-120.
}

\begin{abstract}
The writer analysis five poems by William Blake. The poems are as follows: "Ah sunflower", "The Sick Rose", "A Poison Tree", The Lamb ", and" London. The purpose of this study is to show some results of the study which is limited to diction,figure of speech, and theme. For advance analysis, the writer uses a qualitative approach as a research metodology. While for analysing the three things, the writer uses a descriptive approach that reveals the themes of the five poems. From five of the poems, the writer finds most of dictions are connotation meanings and most of figure of speeches are figurative meanings. Furthermore,the theme of "Ah sun flower" is about death but is not the bad side of death, and the theme of "The Sick Rose" is about a girl who was seriously ill of an illness, then The theme of "A poison Tree"is about the bad side of human nature: anger and desire to win over his enemies., while the theme of "The Lamb" is about religion, namely; the greatness of God, His creations, and His tenderness, and the last one is theme of "London" that is about the London's citizens who experienced injustice from the government throughout Blake's life.
\end{abstract}

Keywords : Literature, poetry,poem

\section{INTRODUCTION}

Literature is one of living phenomena that cannot be separated from human life. Literature is art used to describe written or spoken material or anything from creative writing to more technical or scientific works. Commonly literature used to refer to works of creative imaginations. With literature, human can depict and explore their imaginations, emotional, experiences, and ideas use fiction or nonfiction works. Such as poetry,poem, lyric of songs, film, and or drama.

According to Reed (1946:92) in Barnet, Berman, and Burto (1961); "poetry is attempts to put into words feelings and thoughts. Poetry also attempts to do this in a manner which will make a memorable impression; it uses memory, devices, and ideas, such as figure of speech, rhyme, and rhythm. Poetry was chosen either because of its documentary importance for a full understanding of the period and the works of the major poets, or because of its intrinsic excellence. It means that poetry is describing feelings, reactions, and attitude of the writer about daily life of human beings or poetry can also talk about the fact of social life which will make a memorable impression".

According to Landy (1984:413), states that poetry is musical or at least rhythmic speech. It is also usually a harmonious speech employing words whose sounds echo each other or blend well. It may even be set to music, to be chanted or sung rather than simply spoken.
By this definition, it means that poetry is composition words that ordered with rhyming lines, implying ideas, and its meaning has connection each other. It is also can be ordered in a song. And it will much easier to be remembered by the readers rather than a paragraph on textbook or other sources.

Poetry and poem are different than other types of literary works. They are not only has characteristic which makes them different than ordinary speech or writing, but also the rhythm is unique, and there is beauty in it.

Other theory by Wordsworth, "Poetry is the spontaneous overflow of powerful feelings...the poet's job is to treat of things not as they are... but as they seem to exist to the senses and the passions" (1993:12).

Based on teory above, poem is created through spontaneous depiction of original ideas or powerful feelings or thoughts of a poet. It is portrayal the poet notions, which based on emotions such as sad, cheerful, desperate, sorrow, pleased, miserable, worried, anxious, and disappointed. The poet's job is to process, to treat it as beautiful as possible, so, it depicts something has senses and values which can be felt and imagined by the readers as well.

Another, according to Tolstoy, "Art is a human activity consisting in this, that one man consciously by means of certain external signs, hands on to others feelings he has lived through, and that others are infected by these feelings and also experience them" (1863:223). 
Based on this theory, poem is an art of human activity depicts on words. If a man depicts his feelings, thoughts, ideas and experiences he has faced in his life into a poem, it is also probably will inspire others to depict their ideas, feelings, thoughts, and experiences (Tolstoy, 1863).

Poetry is defined as a literary form of art,evoked in language. It can be written on its own or in combination with other arts as in poetic drama, lyrical poetry, and prose poetry.

Poem is the arangement of words that cantain meaning and musical element. It is a piece of writing the expresses the writer's thoughts and feeling in order to set a mood. It can be happy or sad, simple or complex.

\section{RESEARCH METHODOLOGY}

In doing the research the writer uses qualitative approach as approach of research methodology. Qualitative approach used because this approach describes and provides the assumption and procedures used detaily.

Qualitative approach is the method which does not use statistic data. It is associated to hypothesis generating and developing an understanding. This approach will make this research get deeper information and will be easy to collect the data.

"Qualitative methods (or approaches) the human and social sciences offer several traditions. These traditions may be method types for data collection analysis, and reporting writing, or overall designs that include all phases in the research process". (Creswell, 1944)

Based on the definition above that qualitative method is the human's view through observation that get the fact after analyzing, collecting, reporting, and writing in researching data.

\section{Data Analysis}

In analyzing data the writer uses descriptive method. The aim of this method is to give a description of condition in a situation systematically, accurately, and factually. So, it will be easier to comprehend the meaning of the dictions, figures of speech, and themes.

Descriptive method is a method which is concise in order to get and to analyze data much easier that relate to the matter being studied. By using descriptive method the writer tries to find out the exact and enough description through process and object. Through this method the writer hopes the readers will get the real descriptions about God and its creations, God's grandeur, meekness, death, human nature, suffering, and happiness in William Blake's poems as well

By interpreting will give them its meaning by relating the context in which appears in those poems. In describing the dictions, figures of speech, and themes, the writer bases on formalist theory. It means the data will be analyzed by describing the kinds of dictions, figures of speech, and themes.

Moreover, intrinsic elements also build communication between the readers and the poet. So the readers can understand more about what the poet means in the poems.

It is clearly that analyzing of intrinsic elements is one way to get the content of the text. Moreover it is also helps understanding what the poet wants to show to the readers. It can be used to find out the contents of the poems by William Blake; "Ah Sunflower"," The Sick Rose"," A Poison Tree", "The Lamb", and "London".

\section{FINDING AND RESULT}

In this part the writer explains the data by using table, and the sentences that contain dictions and figures of speech are listed in a table. The poems analyzed are three poems by William Blake; "Ah Sunflower", "The Sick Rose", " A Poison Tree", " The Lamb", and "London". The following are presentation of the descriptions.

\section{Ah Sunflower}

Ah sunflower

Ah Sunflower, weary of time,

Who countest the steps of the sun;

Seeking after that sweet golden clime

Where the traveler's journey is done;

Where the Youth pined away with desire,

And the pale virgin shrouded in snow,

Arise from their graves, and aspire

Where my Sunflower wishes to go!

Based on the lines and appearance, this poem has close structure. This poem is written in 1757. It consists of two quatrains and with rhyming scheme. This classic poem describes about death but it's not the dark side of death. The hope of resurrection and everlasting peace give hope to anyone who believes in the hereafter.

Table 1. Diction in "Ah Sunflower

\begin{tabular}{lll}
\hline Line & Data Findings & Kind of Diction \\
\hline 1 & Ah Sunflower, weary of time & Connotatio \\
\hline 2 & $\begin{array}{l}\text { Who countest the steps of the } \\
\text { sun }\end{array}$ & Connotation \\
\hline 5 & $\begin{array}{l}\text { Where the youth pined away } \\
\text { with desire }\end{array}$ & Denotation \\
\hline
\end{tabular}




\begin{tabular}{lll}
\hline 6 & $\begin{array}{l}\text { And the pale virgin shrouded } \\
\text { in snow }\end{array}$ & Denotation \\
\hline 7 & $\begin{array}{l}\text { Arise from their graves, and } \\
\text { aspire }\end{array}$ & Connotation \\
\hline 7 & $\begin{array}{l}\text { Arise from their graves, and } \\
\text { aspire }\end{array}$ & Denotation \\
\hline
\end{tabular}

Table 2. Figure of Speech in "Ah Sunflower"

\begin{tabular}{lll}
\hline Line & Data Findings & $\begin{array}{l}\text { Kind of figure of } \\
\text { speech }\end{array}$ \\
\hline 1 & Ah Sunflower, weary of time & Metaphor \\
\hline 2 & $\begin{array}{l}\text { Who countest the steps of the } \\
\text { sun }\end{array}$ & Metaphor \\
\hline 3 & $\begin{array}{l}\text { Seeking after that sweet } \\
\text { golden clime }\end{array}$ & Metaphor \\
\hline 6 & $\begin{array}{l}\text { And the pale virgin shrouded } \\
\text { in snow }\end{array}$ & Metaphor \\
\hline 7 & $\begin{array}{l}\text { Arise from their graves, and } \\
\text { aspire }\end{array}$ & Metaphor \\
\hline 8 & $\begin{array}{l}\text { Where my sunflower whises } \\
\text { to go! }\end{array}$ & metaphor \\
\hline
\end{tabular}

\section{Theme of "Ah Sunflower"}

The theme of "Ah Sunflower" is about death, but it's not the dark side of death. It is about the hope of resurrection and everlasting peace, and a yearning to go to better place that is go to the heaven. It gives hope to anyone who believes in the hereafter. It means that if anyone died they do not need to afraid of their next life. Because of death is not something frightening, but death is a resurrection and everlasting peace in hereafter.

\section{The Sick Rose}

\section{The Sick Rose}

O Rose, thou art sick!

The invisible worm

That flies in the nigt,

In the howling storm,

Has found out thy bed

Of crimson joy:

And his dark secret love

Does thy life destroy.

"The Sick Rose" is Blake's poem in the song of experience. Based on the lines and appearance this poem is close structure. This poem is written in 1794. It consists of two quatrains with a rhyme scheme of $\mathrm{ABCB}$, and it sets in the wider context of the songs and represents a fall from the state of innocence. The rose itself symbolizes the innocence, and suggestions that it represents love, and nature. The worm itself symbolizes the destruction of the innocence state.

Table 3. Diction in "The Sick Rose"

\begin{tabular}{lll}
\hline Line & Data Findings & Kind of Diction \\
\hline 1 & O Rose , thou art sick! & Connotation \\
\hline 2 & The invisible worm & Connotation \\
\hline
\end{tabular}

\begin{tabular}{lll}
\hline 5 & Has found out thy bed & Denotation \\
\hline 8 & Does thy life destroy & Denotation \\
\hline
\end{tabular}

Table4. Figure of Speech in "The Sick Rose"

\begin{tabular}{lll}
\hline Line & Data Findings & $\begin{array}{l}\text { Kind of Figure } \\
\text { of speech }\end{array}$ \\
\hline 1 & O Rose ,thou art sick! & Personification \\
\hline 2 & The invisible worm & Metaphor \\
\hline 3 & That flies in the night & Metaphor \\
\hline 6 & Of crimson joy & Metaphor \\
\hline 7 & And his dark secret love & Metaphor \\
\hline
\end{tabular}

\section{Theme of "The Sick Rose"}

"The Sick Rose" is about a dying girl that infected by a disease. It is symbolized with two things that is rose and worm. Where, the rose represents love and nature, while the worm symbolizes the destruction of innocence state. The rose resides in a bed which means the rose is ill; a larger sense of unwellcondition.

\section{A Poison Tree}

\section{A Poison Tree}

I was angry with my friend:

I told my wrath, my wrath did end.

I was angry with my foe;

I told it not, my wrath did grow.

And I water'd it in fears,

Night \& morning with my tears;

And I sunned it with my smiles

And with soft deceitful wiles.

And it grew both day and night,

Till it bore an apple bright;

And my foe beheld it shine,

And he knew that it was mine,

And into my garden stole

When the night had veil'd the pole:

In the morning glad I see

My foe outstretch'd beneath the tree

"A Poison Tree" is one of Blake's poems in song of experience. It was written in 1794. Based on the lines and appearance this poem is close structure and consists of four quatrains, each with rhyming scheme AABB. This poem is about the dark side of human nature; anger and desire to triumph over the enemies. The speaker had a disagreement and felt anger toward his friend and his enemy, because his enemy stole his apple (poison apple) and ate it. Finally the speaker found his enemy died under the tree. The speaker was glad and satisfied.

Table 5. Diction in "Poison Tree"

\begin{tabular}{llll}
\hline Line & Data findings & $\begin{array}{l}\text { Kind } \\
\text { Diction }\end{array}$ & of \\
\hline 4 & $\begin{array}{l}\text { I told it not, my wrath did } \\
\text { grow }\end{array}$ & Connotation \\
\hline
\end{tabular}




\begin{tabular}{lll}
\hline 5 & And I water'd it in fears & Connotation \\
\hline 7 & $\begin{array}{l}\text { And I sunned it with my } \\
\text { smiles }\end{array}$ & Connotation \\
\hline 9 & $\begin{array}{l}\text { And it grew both day and } \\
\text { night }\end{array}$ & Connotation \\
\hline 10 & Till it bore an apple bright; & Connotation \\
\hline 12 & And into my garden stole & Connotation \\
\hline 16 & $\begin{array}{l}\text { My foe outstretch'd beneath } \\
\text { the tree }\end{array}$ & connotation \\
\hline
\end{tabular}

Table 6. Figure of Speech in "A Poison Tree"

\begin{tabular}{lll}
\hline Line & Data Findings & $\begin{array}{l}\text { Kind of Figure of } \\
\text { speech }\end{array}$ \\
\hline 2 & $\begin{array}{l}\text { I told my wrath, my wrath } \\
\text { did end }\end{array}$ & Metaphor \\
\hline 4 & $\begin{array}{l}\text { I told it not, my wrath did } \\
\text { grow }\end{array}$ & Metaphor \\
\hline 5 & And I water'd it in fears & Metaphor \\
\hline 6 & $\begin{array}{l}\text { Night and morning with my } \\
\text { tears }\end{array}$ & Metaphor \\
\hline 7 & $\begin{array}{l}\text { And I sunned it with my } \\
\text { smiles }\end{array}$ & Metaphor \\
\hline 8 & And with soft deceitful wiles & Metaphor \\
\hline 10 & Till it bore an apple bright & Meaphor \\
\hline 12 & And my foe beheld it shine & Metaphor \\
\hline 14 & $\begin{array}{l}\text { When the night had veil'd the } \\
\text { pole }\end{array}$ & Metaphor \\
\hline
\end{tabular}

\section{Theme of "A Poison Tree"}

This poem tells about anger and desire to triumph over the enemies; the dark side of human nature. The speaker anger is toward his friend and his enemy. He had a disagreement with his friend and he can relieve of it. And he also had a disagreement with another person that is his enemy, but towards his enemy he did not express relieve his anger. The enemy grew his fury.

\section{The Lamb}

\section{The Lamb}

A Little Lamb, who made thee?

Dost thou know who made thee?

Gave thee life, and bid thee feed,

By the stream and o'er the mead;

Gave thee clothing of delight,

Softest clothing, woolly, bright;

Gave thee such a tender voice,

Making all the vales rejoice?

Little Lamb, who made thee?

Dost thou know who made thee?

Little Lamb, I'll tell thee,

Little Lamb, I'll tell thee.

He is called by thy name,

For He calls Himself a Lamb.

He is meek, and He is mild;

He became a little child.

I a child, and thou a lamb,

We are called by His name.

Little Lamb, God bless thee!

LittleLamb, God bless thee
"The lamb" is Blake's poem in the song of innocence. It is written in 1789. Based on the line and appearance this poem has close structure. It is a meditation poem; means about a physical object; an animal, but it addresses to God grander and his creation. It has peaceful style.

\section{Table 7. Diction in "The Lamb"}

\begin{tabular}{lll}
\hline Line & Data Findings & Kind of Diction \\
\hline 1 & Little lamb, who made thee? & Connotation \\
\hline 3 & $\begin{array}{l}\text { Gave thee life, and bid thee } \\
\text { feed }\end{array}$ & Connotation \\
\hline 6 & $\begin{array}{l}\text { Softest clothing, woolly, } \\
\text { bright }\end{array}$ & Connotation \\
\hline 13 & He is called by thy name & Connotation \\
\hline 16 & He became a little child & Connotation \\
\hline
\end{tabular}

\section{Table 8. Figure of Speech in "The Lamb"}

\begin{tabular}{lll}
\hline line & Data Findings & $\begin{array}{l}\text { Kindof Figure } \\
\text { of speech }\end{array}$ \\
\hline 1 & Little lamb, who made thee? & Metaphor \\
\hline 3 & $\begin{array}{l}\text { Gave thee life, and bid thee } \\
\text { feed }\end{array}$ & Metaphor \\
\hline 4 & $\begin{array}{l}\text { By the stream and 0'er the } \\
\text { mead }\end{array}$ & Metaphor \\
\hline 5 & $\begin{array}{l}\text { Gave thee clothing of } \\
\text { delight }\end{array}$ & Metaphor \\
\hline 6 & clothing, wooly, bright & Metaphor \\
\hline 7 & $\begin{array}{l}\text { Gave thee such a tender } \\
\text { voice }\end{array}$ & Metaphor \\
\hline 8 & Making all the vales rejoice? & Metaphor \\
\hline 14 & For he calls himself a lamb & Metaphor \\
\hline 15 & He is meek, and he is mild & Metaphor \\
\hline 16 & He became a little child & Metaphor \\
\hline 17 & I a child, and thou a lamb & Personification \\
\hline 20 & Little lamb, God Bless thee! & Metaphor \\
\hline
\end{tabular}

\section{Theme of "The Lamb"}

The theme of this poem is spirituality that is s about god grander, his creations, peace, and meekness. It's clearly stated with the use of the name of God. The poet explains how a higher power created something, and it is described with a physical appearance of an animal as a symbol that is lamb, but virtually it is about God itself and his creations. On the other word, The lamb symbolizes peace and meekness.

\section{London}

"London" is another Blake's poems in the songs of experience. It is written in 1794. Based on the line and appearance this poem has close structure, and it consists of four quatrains with rhyming scheme ABAB. "London" is one of the most famous Blake's poems in his songs of experience. It is a depiction about suffering and unhappiness of London people. The man lack of freedom and the causes of this lack is "the mind forg'd manacles"; attitude which take away of thought and action. 
London

I wander through each chartered street,

Near where the chartered Thames does flow,

And mark in every face I meet,

Marks o fweakness, marks of woe.

In every cry of every man,

In every infant's cry of fear,

In every voice, in every ban,

The mind-forged manacles hear:

How the chimney-sweeper's cry

Every blackening church appals,

And the hapless soldier's sigh

Runs in blood down palace-walls.

But most, through midnight streets I hear

How the youthful harlot's curse

Blasts the new-born infant's tear,

And blights with plagues the marriage-hearse.

Table 9. Diction in "London"

\begin{tabular}{lll}
\hline Line & Data Findings & Kind of Diction \\
\hline 1 & $\begin{array}{l}\text { I wander through each } \\
\text { chartered street }\end{array}$ & Denotation \\
\hline 3 & $\begin{array}{l}\text { And mark in every face I } \\
\text { meet }\end{array}$ & Denotation \\
\hline 4 & $\begin{array}{l}\text { Marks of weakness, marks of } \\
\text { woe }\end{array}$ & Denotation \\
\hline 5 & In every cry of every man & Denotation \\
\hline 6 & In every infant's cry of fear & Denotation \\
\hline 7 & In every voice, in every ban & Denotation \\
\hline 9 & $\begin{array}{l}\text { The mind-forged manacles I } \\
\text { hear }\end{array}$ & Denotation \\
\hline 10 & $\begin{array}{l}\text { How the chimney-sweeper's } \\
\text { cry }\end{array}$ & Denotation \\
& $\begin{array}{l}\text { Every blackening church } \\
\text { appalls }\end{array}$ & Connotation \\
\hline 11 & $\begin{array}{l}\text { And the hapless soldier's } \\
\text { sigh }\end{array}$ & Denotation \\
\hline 14 & $\begin{array}{l}\text { How the youthful harlot's } \\
\text { curse }\end{array}$ & Denotation \\
\hline 15 & $\begin{array}{l}\text { Blast the new-born infant's } \\
\text { tear }\end{array}$ & Denotation \\
\hline & & \\
\hline 9
\end{tabular}

Table 10. Figure of Speech in "London"

\begin{tabular}{lll}
\hline Line & Data Findings & Kind of diction \\
\hline 1 & $\begin{array}{l}\text { I wander through each } \\
\text { chartered street }\end{array}$ & Metaphor \\
\hline 2 & $\begin{array}{l}\text { Near where the chartered } \\
\text { thames does flow }\end{array}$ & Metaphor \\
\hline 4 & $\begin{array}{l}\text { Marks of weakness, marks of } \\
\text { woe }\end{array}$ & Metaphor \\
\hline 8 & $\begin{array}{l}\text { The mind-forged manacles I } \\
\text { hear }\end{array}$ & Metaphor \\
\hline 9 & $\begin{array}{l}\text { How the chimney-sweeper's } \\
\text { cry }\end{array}$ & Hyperbola \\
\hline 10 & $\begin{array}{l}\text { Every blackening church } \\
\text { appalls }\end{array}$ & Metaphor \\
\hline 12 & $\begin{array}{l}\text { Runs in blood down palace } \\
\text { walls }\end{array}$ & Metaphor \\
\hline 15 & $\begin{array}{l}\text { Blasts the new-born infant's } \\
\text { tear }\end{array}$ & Metaphor \\
\hline 16 & And blights with plagues the & Metaphor \\
\hline
\end{tabular}

marriage-hearse

\section{Theme of "London"}

This poem tells about London's citizens. Specifically, it is about Blake's anger towards political times throughout Blake's life. Which means it is about unhappiness; atrocities, poverty, and injustice that happened in London. The man lack of freedom and the causes of this lack is "the mind forg'd manacles"; attitude which take away our freedom of thought and action. The examples of those who are not free are; the chimney sweep, the soldiers, and prostitute. It is something ironic where the fact the monarchy sits within the palace.

\section{a. Analysis of "Ah Sunflower"}

"Ah sunflower" is a classic poem. Ah Sunflower is about a death, but it is not the dark side of death. It is about the hope of resurrection and everlasting peace. Furthermore, person in Ah sunflower is a youth that is girl; a dying girl that infected by a disease. It can be interpreted that this person is a girl because symbol flower usually refers to the youth especially a girl. Like in the first line;

"Ah sunflower, weary of time". The word sunflower in this poem represents connotative meaning. The connotation for the word sunflower gives the hints that the person is young girl. The sunflower has a yearning to go to a better place and most importantly it wants to go to the heaven. The sunflower is just counting down the days or hours of her life. This idea is supported with simple metaphor in the line "Who countest the steps of the sun". The word sun in this line is also represents connotative meaning. The connotation for the word sun could include time or hours of the day. To "countest" is to count something. What is being counted is "the steps of the sun". "Steps of the sun" is interpreted as the movement of the sun or hours of the day. It is just counting down of her life also can be seen in the first line of the poem, "Ah Sunflower, weary of the time". By "weary of the time" can be easily interpreted into being tired with her life.

At the line three and four "Seeking after that sweet golden clime", and "Where the traveler's journey is done". With simple metaphor the poet is creating an image of a person going through difficult tasks before reaching the goal. The goal is that the person is trying to go to the heaven. "And the pale virgin shrouded in snow" at line six, which means that the sunflower dream is deterred and her hope lost. The denotative meaning is also found at line five; youth and desire. The word youth refers to the young person, while the word desire refers to the willingness to get something. Then in the next line the word virgin represents denotative meaning. The denotation of the word virgin is a teenager or young girl. 
Another meaning of this poem in the two last lines at second stanza the speaker expresses his idea with simple metaphor, "Arise from their graves, and aspire", and "Where my sunflower whises to go!", which means that the sunflower wants to go to the better place that she want, that is go to the heaven. Other meanings at the word aspire. The word aspire represents denotative meaning; it has the same meaning with desire; willingness to get something.

\section{b. Analysis of "The Sick Rose"}

"The Sick Rose" is one of Blake's poems in the song of innocence. The sick rose tells about a dying woman or girl. It can be interpreted as a woman because rose is flower. Flower gives the hints that the person is woman. The sick rose has two symbols; they are "rose" and "worm". While the connotation for the word rose has meaning as a woman. In this poem the rose has infected by a worm.

The rose is immediately setting a tone of despair that is by using the word "sick", which carries a larger sense such as "unwell" or "ill". As in the 1st line "O rose, thou art sick!. Then the speaker uses the metaphor in the 2nd line "The invisible worm". It means that the woman is sick because of a disease. The word worm contains connotative meaning that is represents a disease. In the next line the speaker uses hyperbola to express his idea, "That flies in the night" and "In the howling storm". It can be interpreted that the disease attacks the woman in the night when she was sleeping. It suggests work of corruption. It comes and enters the bed at night.

The worm here symbolizes the destruction of the innocence state. It is earthbound that suggests death and decay. The worm is also described as "invisible" thing. As in the 2nd line "The invisible worm".

Another metaphor of this poem is at second stanza. "Has found out thy bed", is interpreted that the rose resides in a bed, which is denoting a human one. In the next line speaker uses metaphor to express his feeling, "Of crimson joy", which is it often used to describe the appearance of blood and suggestion of death. Indeed, a literal death is not suggested, however, a figurative one the rose's life is "destroyed". "And his dark secret love" connotes feelings of jealousy and possessiveness that are explored elsewhere. The words bed and destroy represent denotative meaning. The word bed refers to the place for sleeping or lying down, while the word destroy is refer to the something irreparably.

\section{c. Analysis of "A Poison Tree"}

This poem is used as an extended metaphor, which means explain a dark side of human nature. In the beginning of this poem the speaker tells about his anger toward a friend and an enemy and how each differed. It means that his anger towards his friend can be relieved, but his anger towards his enemy, he did not express it. Like in the 2nd line "I told my wrath, my wrath did end", continuing to 4th line "I told it now, my wrath did grow".

This poem teaches how anger can be dispelled by goodwill or cared to become a deadly poison. The opening stanza sets up everything for the entire line, from the anger with the friend to the continuing anger to the enemy. Besides that in the 1 st stanza also contains the word with connotative meaning.then the writer found out in the 4th line; grow. It can be interpreted that the anger of the speaker toward his enemy cannot be relieved. Even it was getting worse.

In second stanza the speaker described how his wrath toward the enemy was getting grown. By describing the growing and nurturing the tree (it), and the word tree that has connotative meaning, it represents a hate of the speaker. "And I water'd it in fears", "Night and morning with my tears", "And I sunned it with my smiles", and "And with soft deceitful wiles". Then the words water'd and sunned in this stanza contain connotative meaning. Those represent the process of growing the wrath.

In 3rd stanza the speaker described the living nature of the wrath, "And it grew both day and night "(line 9th) and "Till it bore an apple bright"(line 10th). This comparison by metaphor of wrath to a tree describes the speaker idea that like growth of a tree; slow and steady. Anger and wrath gradually accumulate and form something mighty and deadly as a poisoned tree.

The last stanza, in the end of the poem, finally, the speaker killed his enemy. The enemy came into the speaker garden. He stole and ate the poison apple. As in the line 13th and 14th; "And into my garden stole", "When the night had veil'd the pole". In the morning, the speaker found out the enemy dead beneath his tree. The speaker was glad and satisfied to find his enemy dead; "In the morning glad I see", and "My foe outstretch'd beneath the tree".

In this stanza, besides figurative meaning found by the writer it is also contain about diction; connotative words. They are the word garden and the word tree. The word Garden represents the life of the speaker, while the word tree represents the hate or the anger of the speaker.

\section{d. Analysis of "The Lamb"}

"The Lamb" by Blake is a meditation poem written in 1789. It tells about spirituality. A physical object; an animal, but it addresses to the much grander of God and his creations. It's clearly stated with the use of the name God, in the words like "bless thee" and "gave thee life". It also stated with metaphor in the $1 \mathrm{st}$ line;'Little lamb, who made thee?". Then, a gentle 
and meek creature that is "The lamb" represents both daring and submissive creature. A lamb is like a child.

The word "lamb" in this poem represents connotative meaning. It is can be interpreted to Christ; God of Christianity. Christianity is full of allusions to lambs as a sign of peace and meekness. in the line "Gave thee clothing of delight, Softest clothing, wooly, bright" and "Gave thee such a tender voice", those are easy to interpret to the tender curls of the little animal; the lamb. The lamb is calm and spiritual and can give its reader a sense of peace. Then Blake attributes human qualities to a lamb. Throughout the entire of this poem the lamb and the child are interchangeable. Its mean the child is a lamb the lamb is a child. It's a metaphor that extends throughout the poem. Such as in the lines "He became a little child" and "I a child, and thou a lamb". The word child and he in this poem also represent connotative meaning. The connotation for child refers to the lamb and he refers to Christ or God.

The word "thee" is also has connotative meaning which refers to the creations of God. "By the stream and o'er the mead" in fourth line as metaphor refers that god gives the life to his creations by providing them enough water and grass for the lambs, which means for living his creations God not only gives they life but also everything they needs. It's solely for their peace on earth.

At the lines "Little lamb, who made thee?", "Little lamb I'll tell thee", and "Little lamb, God bless thee!". With extended metaphor, those explain how a higher power has created something and it's deeply emotional themes of peace and spirituality.

\section{e. Analysis of "London"}

"London" is one of the most famous Blake's poems in his songs of experience. This poem focuses on the social and political background of London and described the differences between the wealth of the ruling classes and the poverty facing the common people of London. He witnessed the suffering and unhappiness that is related in the poem. He used metaphor in the first stanza (line 1 and 2); "I wander through each chartered street", and "Near where the chartered thames does flow" are describe as charter'd implying that citizens are controlled by the state. The repetitive of the word chartere'd describe Blake's anger at the political times and his feelings towards the ruling classes with their controlling laws and oppressive ways. The words street and face in the first stanza contain denotative meaning. Street refers to the roads of London, while face refers to the citizens of London.

People of London describe as being week and full of woe as the marks and it's reveal on their faces. Like in the fourth line "Marks of weakness, marks of woe".
The repetition of the words marks, it stresses the despair and tiredness that they feel because of their oppressed way of life. Through his feelings of every man and child are suppressed, it is as if the fear and their cries are audible to him as he walks by.

The repetition of the phrases in every in the second stanza; "In every cry of every man", "In every infant's cry of fear" and "in every voice in every ban". It contributes to the sense of urgency. Then the writer could find the words that have denotative meaning. Among them is the word cry. It refers to the weeping of the London people. Then, it is the word man. It refers to the man who populated London. The other is the phrase infant's cry and the words voice and ban. Infant's cry refers to the weeping of the babies, voice refers to the sounds of the people in London, while ban refers to the laws or rules that manacle them.

In the ninth line he mentioned "How the chimneysweeper's cry". It is heavily oppressed group of children who were forced into manual labor with a big risk of their health. Other metaphor in the tenth line says "Every blackening church appals". It suggests both literal pollution and an injustice that horrible. On the other hand the phrase chimneysweeper contains connotative meaning. It can be interpreted as children that populated London.

In the next line with figurative language Blake says "And the hapless soldier's sight", and "Runs in blood down palace wall"(line 11and 12). It suggests that the government is directly responsible for their death. There is something horribly ironic about the fact that monarchy sits within the palace while such atrocities are occurring outside. It means that the functionaries in the palace are enjoying their positions and all of facilities provide, but poverty, atrocity, prostitution and slavery are happening to the masses outside.

At the lines of the last stanza "How the youthful harlot's curse", and "Blasts the new-born infant's tear". It is about other groups of citizens that populated London. With extended metaphor Blake describes a sexually transmitted disease to suggest how injustice is passed by the generations. A lot of youth woman are working as prostitute. And the new generation that is the babies are borne within injustice government. Then the word tear in the 15 th line is also has denotative meaning. It refers to the babies tear that populated in London.

\section{CONCLUSIONS}

In this part the writer conclude the analysis of diction, figure of speech, and theme of five William Blake poems. 
First, in "Ah Sunflower" the writer found out that diction is dominated by denotative meaning. Figure of speech is dominated by metaphor. while, the theme is about death, but it is not the dark side of death. It is a yearning to go to the better place that is go to the heaven. It gives hope to anyone who believes in the hereafter.

Second, in "The Sick Rose" the writer found out that diction is balance between denotative and connotative meaning. Figure of speech is dominated by metaphor, and theme is about a dying girl that infected by a disease. It is symbolized by two things, they are rose which represents love and nature, and worm symbolizes the destruction of innocence state.

Third, in"A Poison Tree" the writer found out that diction is dominated by connotative meaning. Figure of speech is dominated by metaphor, while the theme is about anger and desire to triumph over the enemies; the dark side of human nature. The speaker anger is toward his friend and his enemy.

Fourth, in "The Lamb" the writer found out that diction is also dominated by connotative meaning. In the figure of speech is dominated by metaphor. Meanwhile, the theme is about spirituality; God grander, God creations, peace, and meekness.

Fifth, the last poem "London", the writer found out that diction is dominated by denotative meaning. In the figure of speech is dominated by metaphor. Then the theme is about London's citizens and Blake's anger toward political time throughout Blake's life. Where, unhappiness, atrocities, poverty, and injustice are faced by common people.

Finally, the writer concluded that William Blake poems mostly uses connotative words which stand for something else more abstract. The symbols are also used such as plant symbol found in "Ah Sunflower", ", The Sick Rose", and in "A Poison Tree". And animal symbol found in "The Lamb" and "The Sick Rose". It is important part to convey something that means more than what it is; he can say what he wants indirectly. Each of the intrinsic elements that used gives sense of inner sensation to describe about the situations or conditions and stories in the poems. It will help to comprehend its meaning and will give clear interpretation of the poems.

\section{REFERENCES}

Altenbernd, 1970, in Pengkajian Puisi; analisis strata norma dan analisis structural dan semiotic by Rachmat Djoko Pradopo, 2005 Fakultas Sastra Universitas Gadjah Mada.

Auden, W.H, 1946, in An Introduction to Literature; fiction, poetry, and drama by Sylvan Barnet,
Morton Berman, and William Burto, 1961, Boston; Little, Brown and Company.

Adelina, Heidy, 2001, a thesis of Petra ,University Surabaya.

Brooks, Cleanth, 1959, Understanding Fiction, Appleton-Century-crofts,inc

Beaty, Jerome, Alison Booth, and J.Paul Hunter, Kelly J. Mays, 2002, The Norton Introduction to Literature ,London; W.W Norton Company, inc.

Barnet, Silvan, Morton Berman, and William Burto, 1961, An Introduction to Literature;fiction, poetry, and drama, Boston; Little, Brown and Company

Creswell, John W, 2003, Research Design Qualitative, Quantitative, and Mixed Method Approaches, London; Sage publications, inc.

Coleridge, Samuel Taylor, 1997, in Literature Approaches to Fiction, Poetry, and, Drama by Robert DiYanni, 2004, New York; McGraw-hill Companies, inc.

Creswell, John W, 2008, Educational Research; planning, conducting, and evaluating, qualitative and quantitative Research, USA; Pearson Education, inc.

Creswell, John W, 1994, Research Design Qualitative and Quantitative Approach, London; Sage Publications, inc.

DiYanni, Robert, 2004, Literature Approaches to Fiction, Poetry, and Drama, New York; McGraw-hill Companies, inc.

DiYanni, Robert, 2002, Literature Reading Fiction, poetry, and Drama, New York; McGraw-Hill Companies, inc.

Dewi, Mayasari, 2001, a thesis of Petra University Surabaya.

Emil, and Sandra Roy, 1974, Literary Spectrum, Boston; Allyn and Bacon, inc.

Eviyanti, 2006, a thesis of Pamulang University Tangerang.

\section{WRITER'S BIOGRAPHY}

SRI MULYATI S.S, M.Pd, was born in Kebumen, Central Java. Studied English language at Pamulang University (S1),2011 and English language at IndraPrasta PGRI University (S2),2015. Have been teaching at BSI University since 2012 up to now. A paper have been published entitled: "Pengaruh Penguasaan Kosakata dan Tata Bahasa Terhadap Kemampuan Menulis Bahasa Inggris". 